\title{
A Pilot Study on Sustainable Practices of Malaysian Palm Oil Mills
}

\author{
Vivien Wong Chin Yew*, Azima Abdul Manaf, Er Ah Choy \\ Rosniza Aznie, Suhana Saad, Lim Jie Wei, and \\ Saiful Farisin Md Ramlan
}

\begin{abstract}
Center for Development, Social and Environment, Faculty of Social Sciences and Humanities, The National University of Malaysia, 43600 UKM Bangi Selangor, Malaysia

*Corresponding author. E-mail: vivienyew@ukm.edu.my

https://doi.org/10.12982/CMUJASR.2019.0002
\end{abstract}

\section{ABSTRACT}

Over the past decade, palm oil as an edible vegetable oil has been focus of discussions in the area of sustainability standard for palm oil production. There is a lack of knowledge in terms of sustainable practices in Malaysian palm oil mills particularly among the mills owned by Chinese community in Malaysia. This pilot study aims to determine the gap for Malaysian Chinese millers to attain Roundtable on Sustainable Palm Oil (RSPO) standard in terms of knowledge and documentation. The study explored the following main research question: What are the main issues and challenges faced by Malaysian Chinese palm oil millers in the context of sustainable certification processes? Employing qualitative approach, five Chinese palm oil millers locating in the state of Pahang, Malaysia were selected randomly for in-depth face-to-face interviews and non-participant observations. This field study was conducted in the year of 2017. The study results indicate that Malaysian Chinese palm oil millers place great priority on the environmental management and pollution control policies implemented by the local government through the Department of Environment (DOE). Regular inspections by the local DOE officers on milling's waste management and cleaner production technologies become the management's main point of concentration. Another area of concerns from the Malaysian Chinese millers is the well-being of their mill workers. Other components of RSPO principles and criteria receive moderate attention. In view of the results of this pilot study, it had shown that the Malaysian Chinese millers lack certain knowledge and assistance in documentation in order to qualify the RSPO standard. Thus, a bigger study on this group of Chinese millers should be carried out so that a comprehensive guidelines and documentation software can be developed to assist this group in meeting the world requirements expected of them.

Keywords: Oil palm, Palm oil miller, Sustainability, Malaysia, RSPO, Environmental certification, Standardization, Governance

\section{INTRODUCTION}

As reported in the News Straits Times (Ooi, 2017), Malaysia celebrated 100 years of oil palm planting in 2017. This was to commemorate the success of Henri Fauconnier in planting the first commercial oil palm in 1911 at Tennamaram Estate, Kuala Selangor, as a proposal to replace an unsuccessful coffee estate. This effort of Henri Fauconnier had over the years made Malaysia as the number one trader and second largest palm oil producer in the world. Fauconnier's kind act had then continued to enable palm oil to prosper as one of the healthy edible vegetable oils worldwide. 
Amongst the stiff competition of vegetable oils around the world, palm oil has always been taking as one type of edible vegetable oil that is of lower quality due to its lack of promotion in the Western country. This negative scenario changed on the $16^{\text {th }}$ June 2015 , when the U.S. Food and Drug Administration (FDA) decided to ban the use of trans fats from partially hydrogenated vegetable oils such as soybean oil. It is said that trans fats are unsafe for human consumption (Butler, 2015). The above decision made by U.S. FDA on trans fats had thus opened up broad opportunities for most American households to source for palm oil (a trans fat-free vegetable oil) to serve as a substitute for their previous commonly used oil such as soybean oil.

As most American food manufacturers begin to use palm oil as replacement oil, these American traders apply the same manufacturing standard to the implementation of sustainability in palm oil production and processing. Over the past decade, palm oil as an edible vegetable oil and as a raw ingredient to many packaged products the world population consumes, such as soaps, detergents, fine cosmetics till delicious ice-cream; has been focus of discussions in the area of sustainability standards for palm oil production.

Thus, most American food manufacturers and American consumers demanded that palm oil, either it's an edible vegetable oil, or as a raw ingredient in their favourite products, should be sustainably produced and processed (Chandran, 2014). Both growers and millers of palm oil industry were told to be sustainably certified through criteria and principles of the sustainable board of worldwide standard such as the Roundtable on Sustainable Palm Oil (RSPO).

For the aspect of growers, the sustainable plantation practices would include meeting the universally accepted criteria of benefiting the 3 Ps - profit, people and planet. In Malaysia, sustainable plantation of oil palm has been seen as a balance between economic needs and preservation of the environment, this is enhanced by the installation of the Protection of Wildlife Act 1972. In terms of land use pattern, there is also a balance between agricultural development and preservation of forest areas for conservation of biodiversity (Yusof, 2007).

Whereas milling process for smallholders, the procedures begin with harvesting the ripe bunches of oil palm, collecting them and sending them to the mills for oil extraction. In most cases, smallholders' mills belong to the oil palm plantation owners. For the aspect of sustainability, some of the significant issues being discussed are the issues of Palm Oil Mill Effluent (POME) and the issues of wastewater from palm oil mills (Hansen, 2007). Amongst the millers in Malaysia, the Chinese millers were given less focus when topics regarding sustainable milling process were being discussed. As such, this study aims to explore the sustainable practices of the Malaysian Chinese millers in the aspect of palm oil industry.

\section{PURPOSE OF STUDY}

Oil palm has been one of the agricultural crops that become the focus of debate for sustainability standard. This is so because in the Western countries like America, palm oil is an important ingredient in half of the foods and household products that can be found in the shelves of supermarkets, including ice cream, soaps, detergents, cosmetics, pizzas and candles. Due to the heavy usage of palm oil in the food and household products of the Western countries, consumers particularly the Westerners impose strict and high standards on its growers, millers and suppliers of the ingredient called as palm oil. In Malaysia, growers and millers of oil palm industry, particularly from the smallholders frequently face challenges in the areas of deforestation as well as greenhouse gas emissions (Ilyana Abdullah et al., 2017). 
There is a lack of knowledge in terms of Malaysian Chinese palm oil millers in Malaysia as sustainability certification is concerned. This pilot study aims to determine the gap for Malaysian Chinese to attain RSPO standard in terms of knowledge and documentation. The study explored the following main research question: What are the main issues and challenges faced by Malaysian Chinese palm oil milers in the context of sustainable certification processes? In addition, the study looks into the areas of which principles and criteria in the Roundtable on Sustainable Palm Oil (RSPO) are the most challenging process for them to comply?

\section{LITERATURE REVIEW}

As discussed in the above background of the study, the consumption of palm oil in the global market has increased due to the ban on trans fats in America. As such, the palm oil industry in Malaysia has been growing and is now one of the country's key industries (Chandran, 2014). Its export in 2016 was 16 million tonnes, which occupied $41 \%$ share of global palm oil production and it is the third largest industry in Malaysia after electric goods and oil and gas (MPOB, 2016). The number of palm oil mills in operation in the country is 416 (Chandra, 2014).

In the effort to improve international competitiveness, Malaysian palm oil industry takes steps towards making the industry moving towards sustainable development of palm oil production in Malaysia including the stages of plantation, transport and milling. In the area of oil palm plantations, sustainability means having growing processes focus on the wide usage of fertilizer, and also pesticide use contributes a significant impact towards sustainable development of the industry (Hansen, 2007). For transportation, the sustainable focus is from the combustion of diesel and at the mill the boiler is one of the significant contributors - positively through electricity production and negatively by emissions from the boiler. For milling processes, much has been studied in the areas of waste management.

In Malaysia, research on applying and reviewing sustainable practices in milling processes has been limited. Ilyana Abdullah et al. (2017) in their recent study on milling process, aimed to investigate the implementation of sustainable manufacturing practices in Malaysian palm oil mills by comparing the status of the mills' existing achievements and the levels of priority placed on their practices. Ilyana Abdullah et al. (2017) managed to collect data using five-point Likert scale questionnaire on 20 sustainable manufacturing practices from 51 palm oil mills located in Malaysia. The researchers' findings showed that employees' well-being has the highest level in terms of both priority and existing achievement. However, for other sustainable manufacturing practices, there was a difference where the existing achievement of those practices in the selected palm oil mills was seen to be slightly lower than the priority given to them. An important point worth mention for this research by Ilyana Abdullah et al. (2017) was that the sustainability assessment done on the 51 palm oil mills was an overall assessment that focused on the three dimensions of sustainability, namely the economic, environmental, and social sustainability.

As for other studies on sustainable practices of Malaysia palm oil mills, they are mainly focused on environmental sustainability with areas of study on pollution control, palm oil mill effluent and waste management. A further review of some recent studies on Malaysia sustainable palm oil mills shows several topics of studies such as treatment techniques of palm oil mill effluent (Wu et al., 2009; Rupani et al., 2010; Singh et al., 2010), utilization of oil palm biomass in reducing $\mathrm{CO}_{2}$ (Shuit et al., 2009; Yee et al., 2009; $\mathrm{Ng}$ et al., 2012), and palm oil mill waste management (Embrandiri et al., 2013).

From the above review of previous studies on sustainable practices of Malaysia palm oil 
mills, review of the literature indicated that for most studies, assessment of sustainable practices in a mill was mainly focused on one or two area of practices or milling processes. In view of that, this study seeks to analyse sustainable practices of a palm oil mill in a holistic approach, employing assessment components of the Roundtable on Sustainable Palm Oil (RSPO). More specifically, the study aims to analyse the issues and challenges faced by the Malaysian Chinese palm oil millers in the context of sustainable milling processes.

\section{RSPO Principles and Criteria for Sustainable Palm Oil Millers}

According to RSPO Certification Standards (2007b),

"Sustainable palm oil production is comprised of legal, economically viable, environmentally appropriate and socially beneficial management and operations. This is delivered through the application of the following set of Principles and Criteria, and the accompanying Indicators and Guidance."

The significant point includes in the above statement of sustainable palm oil production by RSPO (2007a) is the sustainability elements that include not only the economic, environmental and social dimensions but also the legal aspect in sustainability issue of palm oil production. All these sustainability elements are being listed in the Eight Principles and Criteria of RSPO as shown in Table 1. These Principles and Criteria of RSPO in regard to sustainable palm oil production do not refer to oil palm growers only but also to include palm oil millers. Selected criteria and indicators shown in Table 1 below are statements that refer more to sustainable management of palm oil mills. The following paragraphs explore the eight RSPO principles in detail.

Table 1. RSPO principles, selected criteria and indicator for palm oil millers.

\begin{tabular}{|c|c|c|c|}
\hline No & Principles & Criteria & Indicators \\
\hline 1. & $\begin{array}{l}\text { Commitment to } \\
\text { Transparency }\end{array}$ & $\begin{array}{l}\text { Oil palm millers provide adequate } \\
\text { information to other stakeholders on } \\
\text { environmental, social and legal issues } \\
\text { relevant to RSPO Criteria, in } \\
\text { appropriate languages \& forms to } \\
\text { allow for effective participation } \\
\text { indecision-making. }\end{array}$ & $\begin{array}{l}\text { Records of requests and } \\
\text { responses must be maintained. }\end{array}$ \\
\hline 2. & $\begin{array}{l}\text { Compliance with } \\
\text { applicable laws and } \\
\text { regulations }\end{array}$ & $\begin{array}{l}\text { The right to use the land can be } \\
\text { demonstrated, and is not } \\
\text { legitimately contested by local } \\
\text { communities with demonstrable } \\
\text { rights. }\end{array}$ & $\begin{array}{l}\text { Documents showing legal } \\
\text { ownership or lease, history of } \\
\text { land tenure and the actual legal } \\
\text { use of the land. }\end{array}$ \\
\hline 3. & $\begin{array}{l}\text { Commitment to } \\
\text { long-term } \\
\text { economic and } \\
\text { financial viability }\end{array}$ & $\begin{array}{l}\text { There is an implemented } \\
\text { management plan that aims to } \\
\text { achieve long-term economic and } \\
\text { financial viability. }\end{array}$ & $\begin{array}{l}\text { A documented business or } \\
\text { management plan (minimum } \\
3 \text { years). }\end{array}$ \\
\hline
\end{tabular}


Table 1. Continued.

\begin{tabular}{|c|c|c|c|}
\hline No & Principles & Criteria & Indicators \\
\hline \multirow[t]{2}{*}{4.} & $\begin{array}{l}\text { Use of appropriate } \\
\text { best practices by } \\
\text { millers }\end{array}$ & $\begin{array}{l}4.1 \text { Operating procedures are } \\
\text { appropriately documented and } \\
\text { consistently implemented and } \\
\text { monitored. }\end{array}$ & SOPs current \& authorised. \\
\hline & & $\begin{array}{l}\text { 4.2 An occupational health and safety } \\
\text { plan is documented, effectively } \\
\text { communicated and implemented. }\end{array}$ & $\begin{array}{l}\text { A health and safety policy, } \\
\text { which is implemented and } \\
\text { monitored. }\end{array}$ \\
\hline \multirow[t]{2}{*}{5.} & $\begin{array}{l}\text { Environmental } \\
\text { responsibility and } \\
\text { conservation of } \\
\text { natural resources } \\
\text { and biodiversity }\end{array}$ & $\begin{array}{l}5.1 \text { Aspects of mill management that } \\
\text { have environmental impacts are } \\
\text { identified, and plans to mitigate the } \\
\text { negative impacts and promote the } \\
\text { positive ones are made, implemented } \\
\text { and monitored, to demonstrate } \\
\text { continuous improvement. }\end{array}$ & $\begin{array}{l}\text { Documented impact } \\
\text { assessment. }\end{array}$ \\
\hline & & $\begin{array}{l}5.2 \text { Waste is reduced, recycled, re- } \\
\text { used and disposed of in an } \\
\text { environmentally and socially } \\
\text { responsible manner. }\end{array}$ & \\
\hline 6. & $\begin{array}{l}\text { Responsible } \\
\text { consideration of } \\
\text { employees and of } \\
\text { individuals and } \\
\text { communities } \\
\text { affected by mills }\end{array}$ & $\begin{array}{l}\text { There are open and transparent } \\
\text { methods for communication and } \\
\text { consultation between growers and/or } \\
\text { millers, local communities and other } \\
\text { affected or interested parties. }\end{array}$ & $\begin{array}{l}\text { Documented consultation and } \\
\text { communication procedures. }\end{array}$ \\
\hline \multirow[t]{2}{*}{7.} & $\begin{array}{l}\text { Responsible } \\
\text { development of new } \\
\text { plantings }\end{array}$ & $\begin{array}{l}7.1 \text { A comprehensive and } \\
\text { participatory independent social and } \\
\text { environmental impact assessment } \\
\text { should be undertaken prior to } \\
\text { establishing new plantings, or } \\
\text { expanding existing ones. }\end{array}$ & $\begin{array}{l}7.1 \text { A documented } \\
\text { independent social and } \\
\text { environmental impact } \\
\text { assessment (SEIA), undertaken } \\
\text { through a participatory } \\
\text { methodology. }\end{array}$ \\
\hline & & $\begin{array}{l}7.2 \text { No new plantings are established } \\
\text { on local peoples' land where it can be } \\
\text { demonstrated that there are legal, } \\
\text { customary or user rights, without } \\
\text { their free, prior and informed } \\
\text { consent. }\end{array}$ & $\begin{array}{l}\text { 7.2 Evidence showing that } \\
\text { affected local peoples } \\
\text { understand they have the right } \\
\text { to say 'no' to operations } \\
\text { planned on their lands before } \\
\text { and during initial discussions, } \\
\text { during the stage of } \\
\text { information gathering and } \\
\text { associated consultations, } \\
\text { during negotiations, and up } \\
\text { until an agreement with the } \\
\text { grower/miller is signed and } \\
\text { formal consent is given by } \\
\text { these local people. }\end{array}$ \\
\hline
\end{tabular}


Table 1. Continued.

\begin{tabular}{|c|c|c|c|}
\hline No & Principles & Criteria & Indicators \\
\hline 8. & $\begin{array}{l}\text { Commitment to } \\
\text { continuous } \\
\text { improvement in } \\
\text { key areas of activity }\end{array}$ & $\begin{array}{l}\text { Millers regularly monitor and review } \\
\text { their activities and develop and } \\
\text { implement action plans that allow } \\
\text { demonstrable continuous } \\
\text { improvement in key operations. }\end{array}$ & $\begin{array}{l}\text { As a minimum, these shall } \\
\text { include, but are not necessarily } \\
\text { be limited to: } \\
\text { - Environmental impacts } \\
\text { - Waste reduction } \\
\text { - Pollution and greenhouse gas } \\
\text { (GHG) emissions } \\
\text { - Social impacts }\end{array}$ \\
\hline
\end{tabular}

Source: RSPO (2007a).

RSPO provides eight principles on the requirements for growers and millers in the palm oil industry to establish, maintain, and improve their operational practices within a management system framework, which enables the adoption of a systematic and integrated approach towards attaining sustainable production of palm oil. The standard covers the areas of operations of the palm oil industry along the whole supply chain including seed production, nursery, estate, smallholdings, mill, kernel crushing, refinery, storage, transport, distribution and management system development and operations. According to Brandi et al. (2012), up to 2012, 34 growers, 154 palm oil mills and a production area of roughly 1.3 million hectares have been certified under RSPO in palm oil-producing countries such as Indonesia, Malaysia, Thailand and Brazil.

According to Table 1 above, the RSPO (2007a) certification criteria for millers entail the following aspects: commitment to transparency; compliance with applicable laws and regulations; commitment to long-term economic and financial viability; use of appropriate best practices by millers; environmental responsibility and conservation of natural resources and biodiversity; responsible consideration of employees and of individuals and communities affected by mills; responsible development of new plantings; and the commitment to continuous improvement in key areas of activity.

From the above indications of the eight (8) principles of RSPO (Table 1), it is obvious that each principle of RSPO is guided by some activities for each Criterion and then its evidence is to be shown through Indicators. According to the document of "RSPO Principles and Criteria for sustainable palm oil production", Indicators are specific pieces of objective evidence that shall (must) be in place to demonstrate or verify that the Criterion is being met. The guidance consists of useful information to help the grower/miller and auditor understand what the Criterion and/or Indicators mean in practice, to indicate malpractice, and practices that should be followed. Given appropriate explanations on the Criteria and Indicators for RSPO principles to be followed by the millers, this study aims to benchmark the sustainable practices of mill management of five Malaysian Chinese palm oil millers, which are found in the state of Pahang, Malaysia against the basic practice of RSPO Principles and Criteria for Sustainable Palm Oil Production by millers particularly.

\section{METHODOLOGY}

This study focuses on the sustainable practices set by the Roundtable on Sustainable Palm Oil (RSPO) - a multi-stakeholders voluntary international standard, as RSPO is one body that develops and implement global standards for sustainable palm oil (RSPO, 2007a). Employing 
qualitative approach, five Malaysian Chinese palm oil millers locating in the state of Pahang, Malaysia were selected randomly for in-depth face-to-face interviews and participant observations during site visits. As the local Malaysian Chinese oil palm smallholder community generally tends to adopt an avoiding attitude when facing government documentation, the main researcher decided to focus on any palm oil millers in the local Chinese community as and when approval to be interviewed from a mill manager was granted.

This field study was conducted in the year of 2017. The process of fieldwork included indepth interviews and checking on millers' related documents on sustainable practice during the milling process. Raw data collection was done through in-depth interviews with five mill managers, age ranged from 28 to 61 years old, during regular site visits in the year of 2017 . As the five male mill managers are English conversant, thus, all the interviews were conducted in English.

Initially, an overview of palm oil production based on eight principles for growers and millers to be RSPO certified was obtained and identified and details related to palm oil millers particularly were determined along with the specific scope of study. The overall data for this study was collected from three different sources:

1. Earlier studies and analysis on the eight principles of sustainable practices for millers based on RSPO certified practices.

2. Field study on in-depth interviews with Malaysian Chinese mill managers and participant observations on actual practices in the mills during site visits.

3. Crosschecks on the documents compiled by the clerical staff of the five Malaysian Chinese millers.

In this study, raw data analysis begin with relying on a common set of principles and for interview data includes: transcribing the interviews; immersing oneself within the data to gain detailed insights into the scenario being explored; and then linking units of data to form categories of text. The next stage of data analysis involves bringing similar categories together into broader themes.

\section{RESEARCH ETHICS}

The main researcher in the very beginning of this study in the early year of 2017 already started to identify these five Malaysian Chinese palm oil millers. However, when contacting the mills' managers, the managers were very uncooperative. All five managers after communicating with their top managements in Kuala Lumpur gave same answers to the main researcher's request to be interviewed on the issue of sustainable palm oil milling process - that is rejection from the headquarters. After several rounds of communicating between the main researcher and the mills' managers, finally all five Malaysian Chinese mill managers agreed to be interviewed but not to mention the actual names of their Malaysian Chinese smallholders' mills as well as not to disclose the names of the five managers. Thus, in this paper, names of mills were addressed as Palm Oil Mill $\mathrm{A}, \mathrm{B}, \mathrm{C}, \mathrm{D}$ and $\mathrm{E}$, whereas, names of the five managers are pseudonyms. In order to respect the managers' request, the main researcher has decided not to mention the actual location of each individual mill in the state of Pahang.

\section{FINDING AND DISCUSSION}

The world today has shifted the focus of maximizing the profit of palm oil production to how well agriculture sector should be organized in order to meet the universally accepted standards of sustainability (Yusof, 2007) - and Malaysia is no exception - developing and enforcing standards 
for sustainable palm oil production.

In Malaysia, smallholder palm oil is produced on estates owned by plantation owners. They also often operate mills where the harvested fruit bunches are processed for oil extraction. Most Malaysian Chinese palm oil millers are categorized under the smallholders' category - Every one of the Malaysian Chinese palm oil millers in this study owns a plantation of 2,000 hectares to 3,500 hectares land areas with its own palm oil mill to process fruits from their plantations as well as surrounding plantations.

Research findings show a comprehensive flow chart of Malaysian Chinese mill process as shown in Figure 1. The processing of palm oil starts with the receipt of fresh fruit bunch (FFB) from the various smallholders or plantation where weighing is carried out, and follow by the grading of the fruits. After this, a sterilization process of the FFB is conducted, a process of cleaning as well as prevention of further deterioration due to internal production of Free Fatty Acids (FFA) in the fruits. Next, the fruits are separated from the bunch by a threshing process and stripped before the palm fruitlets are fed into the digester. The digesting process is to prepare the fruits for a higher efficiency of oil throughput before the oil extraction process of pressing. The extracted crude palm oil will then be filtered to rid off solid wastes by the screening process and be allowed to flow into a clarification tank in order for natural settlement. Basically, the crude palm oil will separate into 2 distinct layers, the upper layer consists of cleaner crude palm oil is ready for the next process of purifying, but the bottom layer contains dirty elements which is drained off to undergo further centrifuging process to eliminate impurities substance before the purifying process. At the purifying process, the crude palm oil is further processed to remove any impurities. Finally, the refined palm oil undergoes drying process to remove moisture and kept in the storage tank.

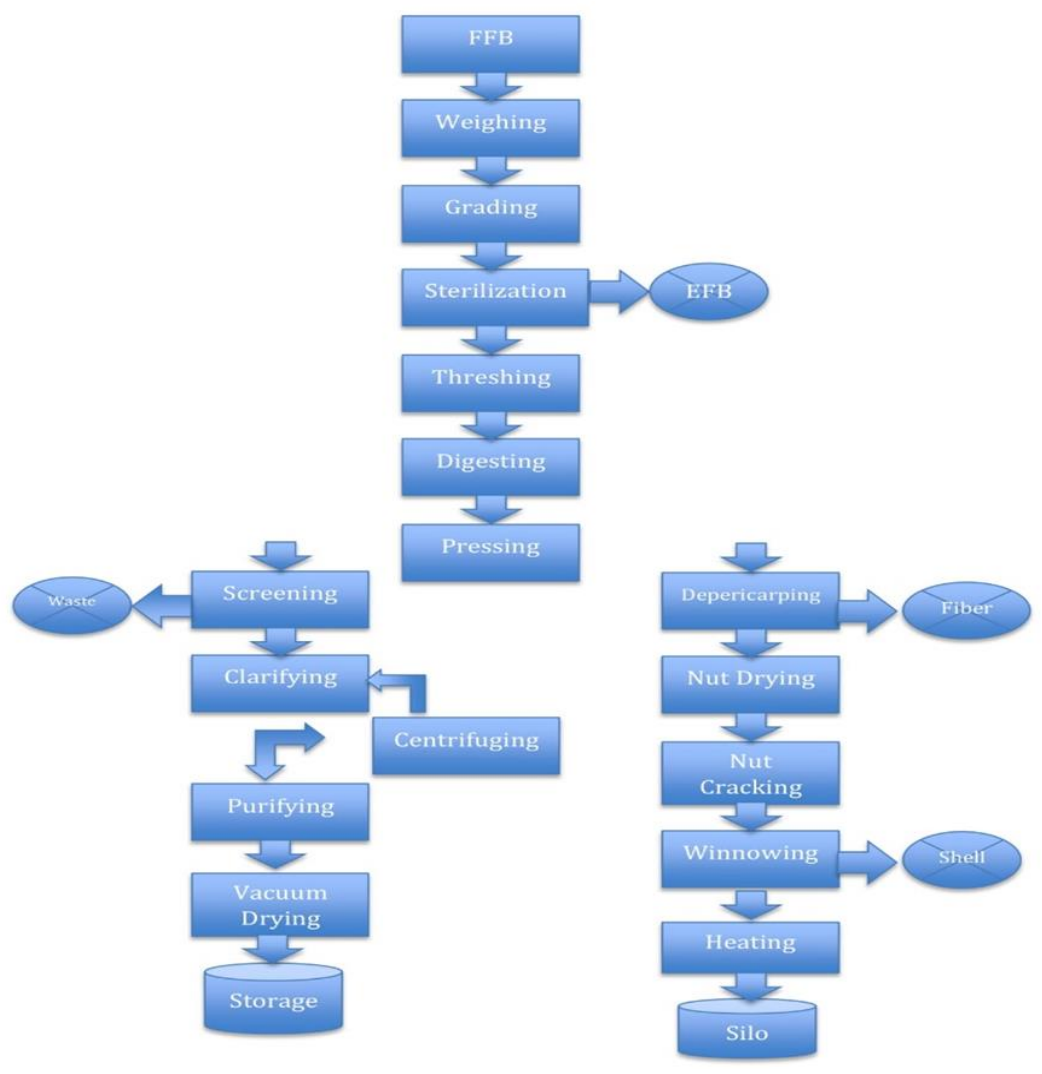

Figure 1. Flowchart of palm oil mill process. 
The nuts of palm fruitlets are separated at the pressing process, which undergoes a different process in order to produce palm kernel oil. In the ensuing processing of nut, they are first dried, then cracked to expose the kernel from the shell, the kernels are then separated from the shell by winnowing process. The kernels are heated and stored in the silo before delivery to kernel processing plant for further processing into the final product of palm kernel oil.

Further analysis on the results of this study places more emphasis on the possible application of the eight RSPO Principles and Criteria as per listed in Table 1, for sustainable palm oil milling processes. The analysis of data from in-depth interviews, participant observations and content analysis on mill's documents for sustainability practices are presented according to the themes as elaborated below such as inefficiency in documentation on the ground, leaving the comfort zone is hard and risky, ad hoc troubleshooting approach over structured troubleshooting approach, and legal and regulatory compliance particularly from Department of Environment (DOE) and the mill workers' wellbeing.

\section{Inefficiency in documentation on the ground}

For Principle 1 - Commitment to Transparency and Principle 2 - Compliance with applicable laws and regulations, in the context of milling practices. For these two Principles, palm oil is considered as a sustainable product if the milling processes comply with local, national and international rules and regulations. Between the two Principles, the five Malaysian Chinese palm oil millers have easily fulfilled Principle 2 . The company staff made an effort to present documents that are showing legal ownership and the actual legal use of the plantation land.

However, Principle 1 indicates that Malaysian Chinese palm oil millers are to provide adequate information to other stakeholders on environmental, social and legal issues relevant to RSPO Criteria, in appropriate languages and forms to allow for effective participation in decisionmaking. For this aspect, these five palm millers seem to be quite unable to present records of requests and responses that used to be maintained all these years.

\section{The government asks for proper documentation on all our operation procedures. I think this is a very tedious job. This task requires us to employ a full-time staff to manage. We do not have such budget. \\ It is possible to prepare those required documents. However, there is no space to keep all those documents in the plant. Our office is very small and not suitable for keeping the whole set of documentation.}

As the millers interviewed had given various negative reasons in responding to proper documentation for certification of RSPO, this research finding gives an interpretation that they are basically refused to make changes so as to meet the requirement of RSPO.

\section{Leaving the comfort zone is hard and risky}

Principle 3 indicates that to be a sustainable palm oil mill, the mill must have an implemented management plan that aims to achieve long-term economic and financial viability. This aspect of the RSPO Principles is seen difficult to be complied by the Malaysian Chinese millers. It was explained by the Palm Oil mill managers that their mills have been operating for more than 10 years. Everything in the mill has been running smoothly including the economic and financial activities. As such, the Mill Managers do not see if it is necessary for the top management to have a 3 or 5 years economic and financial forecast plan. 
This plant has been operating for about 10 years already. We have been running the plant based on our previous experiences and knowledge accumulated over the past 10 years or so. That's the reason it is difficult for us at the plant to receive a 5 year economic and financial forecast plan.

We think that we have been already comfortable with the running of this plant. There is no need to make any changes, such as to upgrade our plant status to meet.

I guess our top management just wanted to play safe. After all, we have been making profit all these years.

The research findings indicated that the palm oil millers in this study would like to minimize risks. This approach engaged clearly portrays the common characteristic of the Chinese culture in fearing failure as they are outside the comfort zone. The millers would rather stay within the safe gates of their comfort zone, not venturing out because of failure that comes with any change in their milling process that includes proper documentation.

\section{Ad hoc troubleshooting approach over structured troubleshooting approach}

The same attitude of management for Principle 3 is seen in Principles 7 and 8 - Millers regularly monitor and review their activities and develop and implement action plans that allow demonstrable continuous improvement in key operations. Constant review and monitor of action plans were thought to be unnecessary. Although most of the Malaysian Chinese mill managers acknowledged that when they perform structured troubleshooting in the mills, they are able to make continuous progress and sometimes solve the problem faster than it would take using an ad hoc troubleshooting approach. However, the Malaysian Chinese millers would still prefer to be employing ad hoc action plan as and when there are unforeseen circumstances occur in the mill or even in the plantation.

I understand that if we were to comply with RSPO, we must prepare very good structured troubleshooting procedures for any emergency to happen in the plant. This is definitely not practical for us. Because we will not be able to forecast what will happen, right?

Nowadays, working with the foreign workers, different culture and many of them have not worked in a palm oil plant before. Anything can happen in the plant.

In the preference of ad hoc troubleshooting approach when facing physical problems in the mills, the Malaysian Chinese millers seem to adopt a Chinese culture whereby if there is a structure troubleshooting approach on problems, this will unconsciously create unnecessary physical problems such as minor accidents on workers or milling machines failure.

\section{Legal and regulatory compliance-DOE and workers wellbeing}

The Malaysian Chinese palm oil millers are however good in applying Principles 4, 5 and 6, of which Standard Operating Procedures are appropriately documented and consistently implemented and monitored. Some of the indicators in these 3 Principles refer to Best Management Practices, Safe Working Practices and Non-discriminatory Practices. Three Malaysian Chinese Millers of the five had actually won the above awards for several years consecutively.

In terms of environmental control, we have got no problem at all. The DOE officers will come and check our surroundings, inside and outside our plant. We always make sure we do not receive any summons from these government officers. 
Chinese always do not like to be associated with the police station. If we do not comply with DOE's requirements, we will be called to court. This is something not wanted by our top management.

The good practices of the millers in taking care of the mill's environment as well as their workers' wellbeing further develop high employee morale. A clean and happy working environment coupled with mill healthy workers improves mills' productivity and continued to achieve the RSPO regulations.

Overall, the study results indicate that Malaysian Chinese palm oil millers place great priority on the environmental management and pollution control policies implemented by the local government through the Department of Environment (DOE). Regular inspections by the local DOE officers on milling's waste management and cleaner production technologies become the management's main point of concentration. Another area of concerns from the Malaysian Chinese millers is the wellbeing of their mill workers. Other components of RSPO principles and criteria receive moderate attention though the results show several areas of RSPO need further investigation and consultation with the Malaysian Chinese palm oil millers as a whole.

\section{CONCLUSION}

Study findings show that Malaysian Chinese palm oil millers have been applying sustainable practices in some of the areas of RSPO's standard. This is mainly due to the Chinese' cautious attitude of not wanting to receive summons from the local governments if their practices related to palm oil milling process do not comply with the standards set by certain control agency such as the Department of Environment. Chinese culture unconsciously plays a significant role in managing the palm oil milling process among the Malaysian Chinese millers. Nevertheless, RSPO certification of Malaysian Chinese palm oil millers shows several challenges, as it demands a set of documentation and managerial capacities, which in most cases most of the Malaysian Chinese millers lack. However, Malaysian Chinese millers ought to be capable of maintaining its position in the future, and it's important that they supply international standard of sustainable palm oil.

\section{ACKNOWLEDGEMENTS}

The cost of the field study as well as the publication of this paper is borne by the MPOBUKM Endowed Chair Research Grants (Research Codes: EP-2019-054, EP-2017-061 and EP2015-072).

\section{REFERENCES}

Brandi, C., Toboas, C., Christoph, H., Sonja, S., Lotte, W., \& Hannah, W. (2012). Sustainability standards and certification: towards sustainable palm oil in Indonesia? Briefing Paper. Germany: German Development Institute (DIE), Bonn.

Butler, R.A. (2015). FDA bans artificial trans fats, paving way for more U.S. palm oil consumption. Retrieved from https://news.mongabay.com/2015/06/fda-bans-artificialtrans-fats-paving-way-for-more-u-s-palm-oil-consumption/

Chandran, M.R. (2014). Getting our act together: Sustainability in the Malaysian palm oil industry. Retrieved from http://www.eco-business.com/opinion/getting-our-act-together-sustainabi litymalaysian-palm-oil-industry/ 
Embrandiri, A., Ibrahim, M.H., \& Singh, R.P. (2013). Palm oil mill wastes utilization; sustainability in the Malaysian context. International Journal of Scientific and Research Publication, 3(3), 63-68.

Hansen, S. (2007). Feasibility study of performing a life cycle assessment on crude palm oil production in Malaysia. The International Journal of Life Cycle Assessment, 12(1), 50-58. https://doi.org/10.1065/lca2005.08.226

Ilyana, A., Wan Mahmood, W.H., Faudi, H.F. Md., Rahman, M.N.A., \& Mohamed, S.B. (2017). Sustainable manufacturing practices in Malaysian palm oil mills: Priority and current performance. Journal of Manufacturing Technology Management, 28(3), 278-298. https://doi.org/10.1108/JMTM-09-2016-0128

Malaysia Palm Oil Board. (2016). Export of palm oil by Port 2016 (tonnes). Economics and Industry Development Division. Retrieved from http://bepi.mpob.gov.my/index.php/ en/statistics/ export/171-export-2016/764-palm-oil-export-by-major-ports-2016.html

Ng, W.P.Q., Lam, H.L., Ng, F.Y., Kamal, M., \& Lim, J.H.E. (2012). Waste-to-wealth: green potential from palm biomass in Malaysia. Journal of Cleaner Production, 34, 57-65. https:// doi.org/10.1016/j.jclepro.2012.04.004

Ooi, T.C. (2017). Brighter outlook for palm oil in 2017. Retrieved from https://www.nst.com. my/news/2017/01/203279/brighter-outlook-palm-oil-2017

Palm Oil Research. (2014). Untangling the great palm oil debate. Retrieved from http://www. palmoilresearch.org/statistics.html

RSPO (Roundtable on Sustainable Palm Oil) (2007a). RSPO principles \& criteria for sustainable palm oil production.

RSPO (2007b). Certification Systems. Final document approved by RSPO Executive Board. Retrieved from http://rspo.org/sites/default/files/RSPOcertification-systems.pdf

Rupani, P.F., Singh, R.P., Ibrahim, M.H., \& Esa, N. (2010). Review of current palm oil mill effluent (POME) treatment methods: Vermicomposting as a sustainable practice. World Applied Sciences Journal, 11(1), 70-81.

Singh, R.P., Ibrahim, M.G., Esa, N., \& Iliyana, M.S. (2010). Composting of waste from palm oil mill: a sustainable waste management practice. Reviews in Environmental Science and Bio/Technology, 9(4), 331-344. https://doi.org/10.1007/s11157-010-9199-2

Shuit, S.H., Tan, K.T., Lee, K.T., \& Kamaruddin, A.H. (2009). Oil palm biomass as a sustainable energy source: a Malaysian case study. Energy, 34(9), 1225-1235. https://doi.org/10.1016/ j.energy.2009.05.008

Wu, T.Y., Mohammad, A.W., Jahim, J.M., \& Anuar, N. (2009). A holistic approach to managing palm oil mill effluent (POME): biotechnological advances in the sustainable reuse of POME. Biotechnology Advances, 27(1), 40-52. https://doi.org/10.1016/j.biotechadv. 2008.08.005

Yee, K.F., Tam, K.T., Abdullah, A.Z., \& Lee, K.T. (2009). Life cycle assessment of palm biodiesel: revealing facts and benefits for sustainability. Applied Energy, 86, 189-196. https://doi. org/10.1016/j.apenergy.2009.04.014

Yusof, B. (2007). Palm oil production through sustainable plantations. European Journal of Lipid Science and Technology, 109(4), 289-295. https://doi.org/10.1002/ejlt.200600223 